\title{
Xibe Chinese
}

National Cancer Institute

\section{Source}

National Cancer Institute. Xibe Chinese. NCI Thesaurus. Code C158188.

A Chinese person from the Xibe ethnic group. 